\title{
Ectopic Tooth in the Maxillary Sinus
}

\author{
Özgül Topal ${ }^{1}$, Ezher Hamza Dayısoylu² \\ Clinical Image $>\begin{aligned} & { }^{2} \text { Department of Otorhinolaryngology, Başkent University School of Medicine, Ankara, Turkey } \\ & \text { 'Department of Oral and Maxillofacial Surgery, Başkent University School of Dentistry, Ankara, Turkey }\end{aligned}$
}

Odontogenesis occurs because of a multi-stage complicated interaction between the oral epithelium and the mesenchymal tissue under the epithelium. Abnormal tissue interactions during this process can lead to ectopic tooth development (1). Ectopic tooth outside the oral cavity is rarely reported in the literature $(1,2)$ Ectopic teeth can be asymptomatic or can form odontogenic cysts, cause degradation of the bone, and can be the source of focal infection $(3,4)$.

A 32-year-old female patient with complaints of increasing swelling of the left side of her face and pain radiating to the eye, left upper teeth, and ear was admitted to the Clinic of Otorhinolaryngology. She had no history of any previous surgery. The results of routine ear-nose-throat examination and nasal and nasopharyngeal endoscopic examination were found to be normal. Her left buccal mucosa was diffusely edematous. Computed tomography revealed a mass lesion that completely filled the left maxillary sinus, obliterated the ostiomeatal unit, and caused destruction of the lateral wall of the sinus; it also showed a tooth in the medial wall of the sinus (Figure 1). In addition, magnetic resonance imaging revealed an inflammation related contrast material opacification spreading to the buccinator area and retromolar trigone mucosa on the left (Figure 2). The patient underwent surgery under general anesthesia using a combined approach of endoscopy and Caldwell-Luc procedure and the tooth in the sinus and surrounding inflamed tissues were cleaned. Histopathological examination results of the surgical specimen revealed active chronic inflammation. The results of the clinical examination within the first postoperative year revealed that the maxillary sinus ostium was open and that the inside of the sinus was clean in endoscopic evaluation.
Ectopic tooth is rarely encountered in the maxillary sinus. In the literature, ectopic tooth has been reported to occur in some unusual localization such as the palate, mandibular condyle, coronoid process, orbita, and nasal cavity. The causes of developing an ectopic tooth are not exactly known. These teeth can result from developmental anomalies, uneven teeth, trauma, and iatrogenic or idiopathic factors (2). In our case, we believe that because the impacted third molar tooth could not find a place in the alveolar arch owing to the narrow maxillary area, it ectopically erupted in the sinus.

Ectopic teeth are mostly asymptomatic. Nevertheless, impacted teeth can lead to orofacial pain because of their localizations; they can also imitate temporomandibular joint pain; they can be a source of focal infection; or the pathology can lead to the development of odontogenic cyst or odontogenic tumor in association with dysplasia of the surrounding follicle (5-7). In our case, the main complaints were facial swelling and pain developing secondary to complicated chronic sinusitis associated with ostiomeatal complex obstruction.

The diagnosis of ectopic tooth can be easily radiologically established, particularly when they localize to the maxillary sinus. Surgical treatment is required in symptomatic cases. The type of surgical intervention should be decided based on the patient $(8,9)$. In our case, we preferred the combined approach of endoscopic sinus surgery and Caldwell-Luc procedure. In endoscopic approaches, it can be difficult to reach the lateral, anterior, and inferior walls of the maxillary sinus. Therefore, combined approaches are required in some situations (9). In our case, the eroded lateral wall of the 

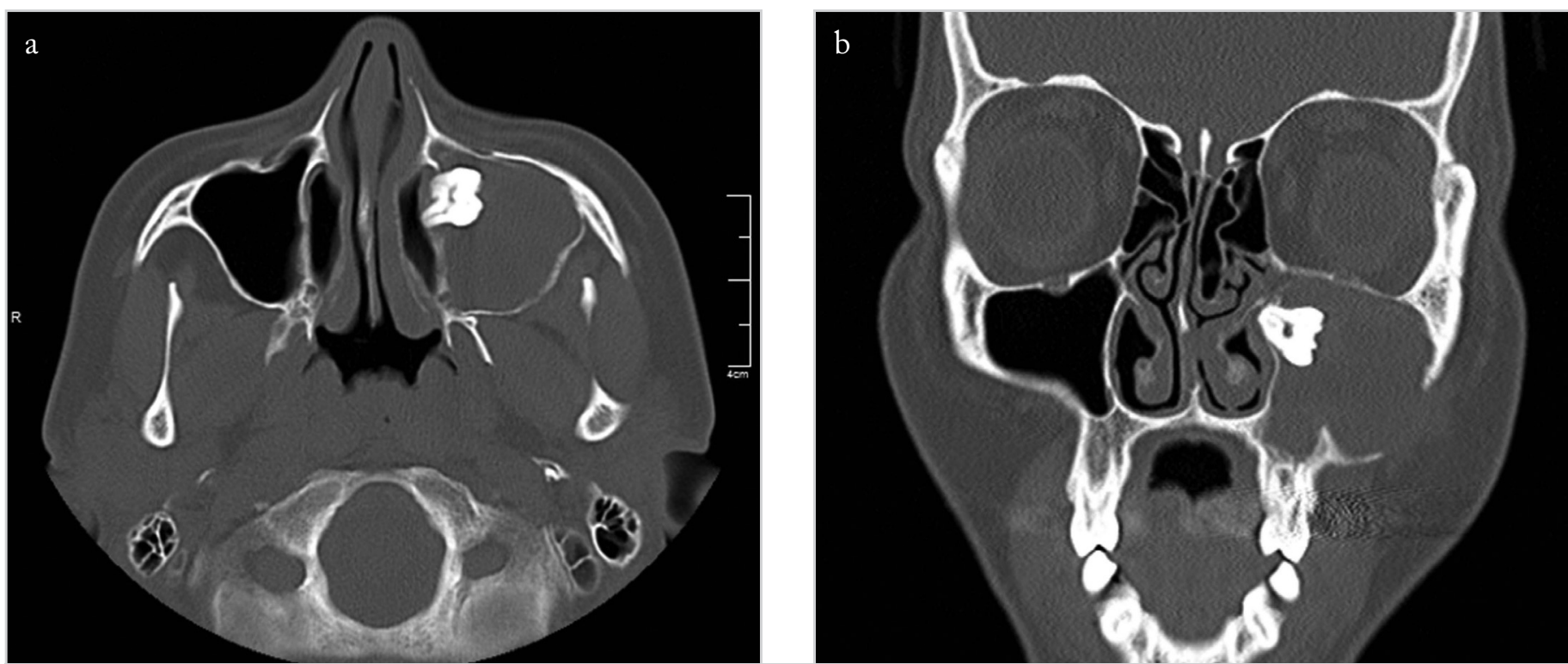

Figure 1. a, b. Computed tomography of the paranasal sinus showing ectopic tooth in the medial wall of the left maxillary sinus and maxillary sinusitis: (a) axial and (b) coronal sections

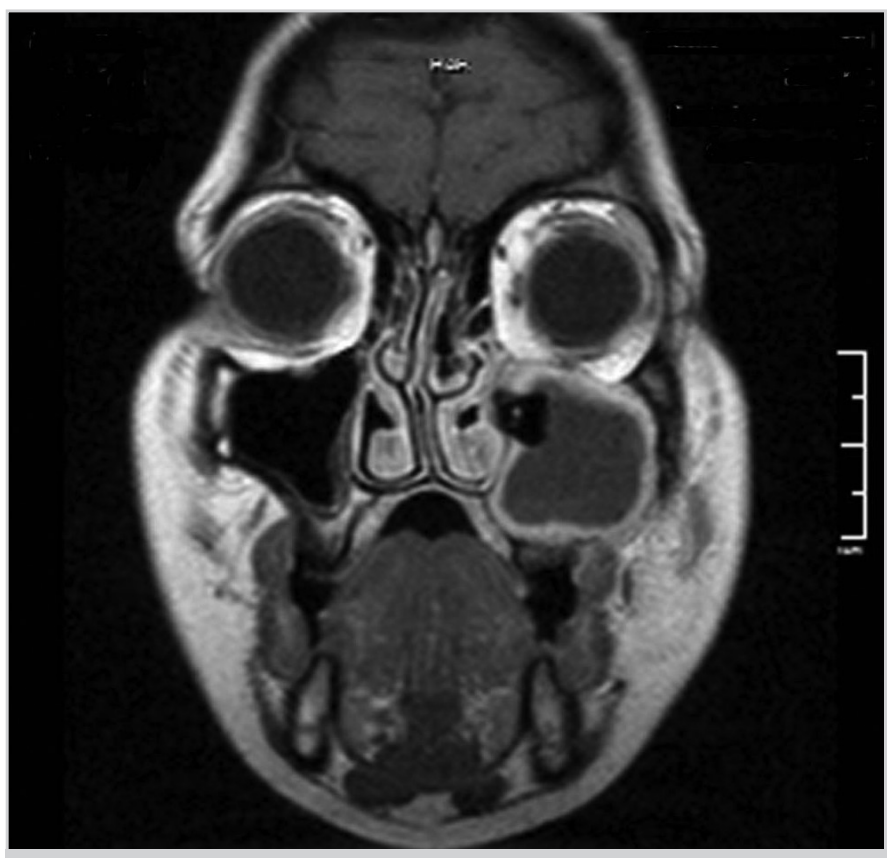

Figure 2. Magnetic resonance imaging showing ectopic tooth in the left maxillary sinus and contrast enhancement due to soft tissue inflammation ( $\mathrm{T} 1$, contrast-enhanced coronal section)

sinus and inflammation of the soft tissue in the buccinator plane necessitated the use of the Caldwell-Luc procedure. Meanwhile, the addition of endoscopic intranasal surgery provided aeration and nasal vizualization of the maxillary sinus area, which was highly expanded because of inflammation and bone degradation by re-opening and enlarging the closed sinus ostium.

Incidentally detected asymptomatic cases should be regularly followed up with regard to cystic degeneration in the epithelium surrounding the tooth, destruction in the adjacent bone, or potential damage to vital structures (8). However, as in our case, surgical treatment is required for complicated patients.
Peer-review: Externally peer-reviewed.

Author Contributions: Concept - Ö.T., E.D.; Design - Ö.T.; E.D.; Supervision - Ö.T., E.D.; Resource - Ö.T., E.D.; Materials - Ö.T., E.D.; Data Collection and/or Processing - Ö.T., E.D.; Analysis and/or Interpretation - Ö.T., E.D.; Literature Search - Ö.T., E.D.; Writing - Ö.T., E.D.; Critical Reviews - Ö.T., E.D.

Conflict of Interest: No conflict of interest was declared by the authors.

Financial Disclosure: The authors declared that this study has received no financial support.

\section{References}

1. Bodner L, Tovi F, Bar-Ziv J. Teeth in the maxillary sinus- imaging and management.J Laryngol Otol 1997; 111: 820-4. [CrossRef]

2. Buyukkurt MC, Omezli MM, Miloglu O. Dentigerous cyst associated with an ectopic tooth in the maxillary sinus: a report of 3 cases and review of the literature. Oral Surg Oral Med Oral Pathol Oral Radiol Endod 2010; 109: 67-71. [CrossRef]

3. Persac S, Prévost R, Hardy H, Gigon S, Peron JM. An update on focal infection of oral origin. Rev Stomatol Chir Maxillofac 2011; 112: 353-9. [CrossRef]

4. Verma RK, Kumar R, Bal A, Panda NK. Aneurysmal bone cyst of maxilla with ectopic molar tooth - a case report. Otolaryngol Pol 2013; 67: 302-7. [CrossRef]

5. Mermod M, Broome M, Hoarau R, Zweifel D. Facial pain associated with CPAP use: Intra-sinusal third molar. Case Rep Otolaryngol 2014; 2014: 837252. [CrossRef]

6. Zhang Y,Xu Y,Xu Y, Tao Z. Extramedullary plasmacytoma associated with an ectopic tooth in the nasal cavity. Ear Nose Throat J 2015; 94: E43-6.

7. Baykul T, Doğru H, Yasan H, Aksoy MÇ. Clinical impact of ectopic teeth in the maxillary sinus. Auris Nasus Larynx 2006; 33: 277-81. [CrossRef]

8. Elonga S, Palaniappan SP. Ectopic tooth in the roof of the maxillary sinus. Ear Nose Throat J 1991; 70: 365-6.

9. Schneider JS, Day A, Clavena M, Russell PT, Duncavage J. Early practice: External sinus surgery and procedures and complications. Otolaryngol Clin N Am 2015; 48: 839-50. [CrossRef] 